\title{
Formação do Psicólogo: Experiências de Militantes Estudantis
}

Psychologist professional preparation: College militancy experience college

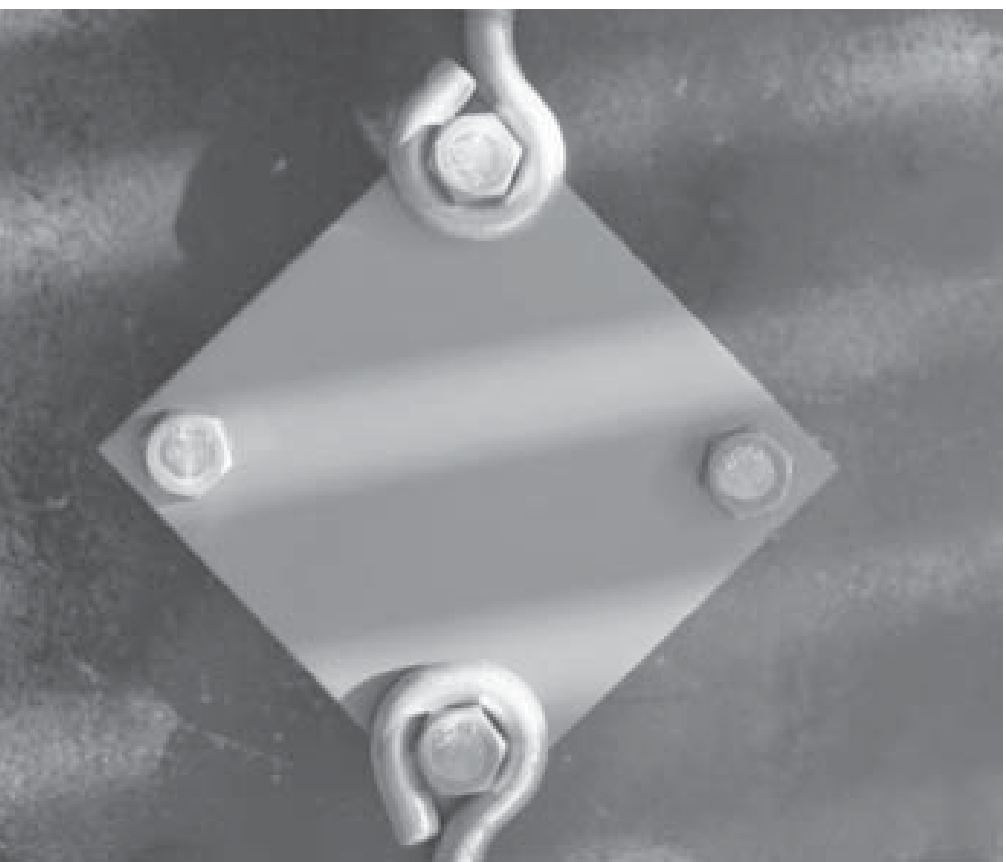




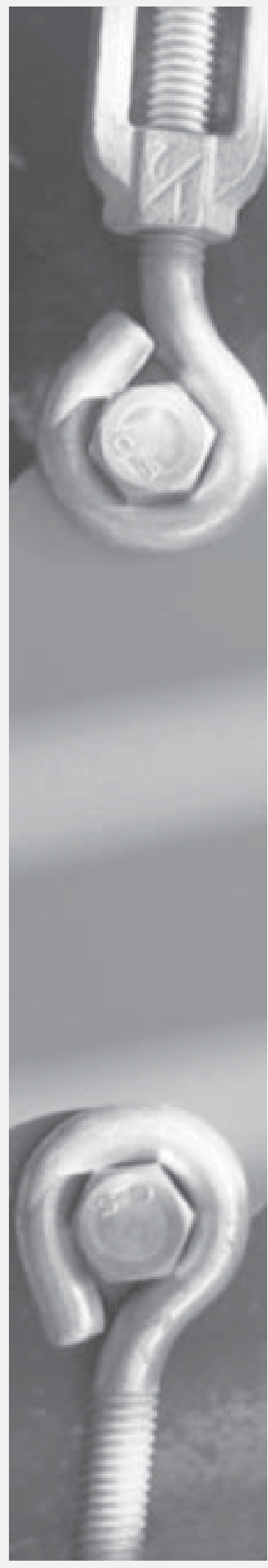

Resumo: Este artigo é fruto de investigações iniciadas durante pesquisa de mestrado orientada metodologicamente pelos trabalhos de Ecléa Bosi e José Moura Gonçalves Filho, enfocando memórias de militantes estudantis. Um dos temas lembrados com maior destaque foi a relação entre Psicologia e ideologia. Durante a graduação, espaços e interesses da militância universitária por vezes estabeleceram radical antagonismo frente às aulas e mesmo a colegas e professores; outras vezes, militância e Psicologia foram combinadas na experiência e prática políticas. Através da memória de militantes estudantis, da análise de suas trajetórias desde o ingresso na universidade até os primeiros anos depois de formados, pretendemos melhor compreender as angústias daqueles que procuram integrar práticas profissionais e compromisso social. Pretendemos contribuir, assim, para a reflexão acerca da formação do psicólogo, atinando para o que nela representa convite ao pensamento crítico e à ação transformadora ou que, pelo contrário, induz à legitimação das desigualdades sociais.

Palavras-chave: formação do psicólogo, ideologia, movimento estudantil.

Abstract: This article is the result of investigations that started during the Master's degree research and that were methodologically oriented by the work of Ecléa Bosi and José Moura Gonçalves Filho, whose focus is the memories of militant students. One of the themes most emphatically remembered was the relation between Psychology and ideology. During under graduation, spaces and university militancy interests were sometimes radically antagonistic to the course, the classes and even lassmates and professors; at other times, militancy and Psychology were joined in experience and political practice. Through the memories of militant students, analyzing their history since the beginning of university until the first years after under graduation, we intend to understand better the anxieties of those who try to integrate professional practice to social commitment. This way we intend to contribute for the reflection on the psychologist professional preparation, considering that this preparation may lead to a critical thought and a transformational action, or, on the contrary, may lead to a confirmation of social inequality.

Key words: professional preparation of the psychologist, ideology, student militancy. 


\section{Os compromissos da Psicologia e a perspectiva do militante}

Psicólogos, em diferentes áreas, se deparam com antagonismos entre sua formação e compromisso social. Em escolas, hospitais, aparelhos de saúde mental e universidades, profissionais se situam entre uma tradição que deita raízes na reprodução do status quo e um corpo teórico e técnico que, nascido desse passado, procura sua subversão. Conflito radicado na história da Psicologia, tem sido tema de estudo e fonte de angústia desde longa data.

Maria Helena Souza Patto (1984) afirma que o saber psicológico, em sua origem, representa um importante instrumento de dominação. Com seu advento, para compreender a si e aos outros, é necessário passar pelos "especialistas da subjetividade".

No território da

terapia,... seu objetivo é a cura, "simples processo de adaptação a normas que mantêm o status quo e que têm como valores supremos a saúde, a maturidade e o êxito, assimilando amore produtividade e baseando os valores culturais numa vasta harmonia que unicamente o indivíduo poderia romper.
As técnicas de mensuração e quantificação dão aparência neutra aos juízos; o sofrimento, frente a uma situação real de opressão, pode ser concebido como sintoma de inadaptação, e aquilo que poderia ser interpretado como resistência saudável torna-se patologia ou algum tipo de déficit mental. Nas palavras da autora, "a Psicologia nasce com a marca de uma demanda: a de prover conceitos e instrumentos 'científicos' de medida que garantam a adaptação dos indivíduos à nova ordem social" (1984, p. 96).

À guisa da diversidade de linhas e campos de atuação, encontra-se um comprometimento originário:

... "sob a aparente heterogeneidade da Psicologia, constituída por várias escolas ou vários paradigmas, seria possível detectar a presença de uma unidade básica; isto equivale a afirmar que o behaviorismo de Watson e suas versões mais recentes não detêm a exclusividade de constituírem um discurso ideológico adaptacionista, com pretensão ao status de ciência. A mesma reificação que identificamos no discurso comportamental talvez esteja presente no pensamento cognitivista e humanista, materializados nos fundamentos teóricos do movimento psicometrista (seja o que se configura na construção e aplicação dos testes de aptidão, seja o que se caracteriza pelos instrumentos de avaliação da personalidade), na teoria piagetiana, no psicodrama e no sociodrama, na Psicologia social de inspiração funcionalista, na teoria de personalidade e de terapia centrada no cliente. (...)

No território da terapia,... seu objetivo é a cura, "simples processo de adaptação a normas que mantêm o status quo e que têm como valores supremos a saúde, a maturidade e o êxito, assimilando amor e produtividade e baseando os valores culturais numa vasta harmonia que unicamente o indivíduo poderia romper. Nesse nível, a neurose é, acima de tudo, um problema de ordem moral, e o protesto humanista que acompanha a denúncia da mecanização e da perda do sentido do 'espiritual' se reduz a uma apologia da vontade e da coragem de ser 'si mesmo' " (Deleuze, p. 109). A opacidade das relações de classe é, assim, substituída pela transparência das relações humanas" (Patto, 1984, pp. 93-95).

O compromisso da Psicologia tem raízes profundas. Suas teorias e técnicas compõem a totalidade de uma perspectiva que não é sempre consciente, sempre enunciada, mas está presente nas perguntas que o psicólogo faz, na direção que dá à sua intervenção, às suas pesquisas e temas de estudo. Segundo Marilena Chauí, 
"A ideologia é um corpo sistemático de representações e de normas que nos "ensinam" a conhecer e agir. A sistematicidade e a coerência ideológicas nascem de uma determinação muito precisa: o discurso ideológico é aquele que pretende coincidir com as coisas, anular a diferença entre o pensar, o dizer e o ser e, destarte, engendrar uma lógica da identificação que unifique pensamento, linguagem e realidade para, através dessa lógica, obter a identificação de todos os sujeitos sociais com uma imagem particular universalizada, isto é, a imagem da classe dominante" (1997, pp. 3-4).

Trata-se, portanto, de algo mais poderoso que um conjunto de idéias equivocadas ou malintencionadas. Na Psicologia, existe um compromisso originário presente nos enunciados teóricos, na linguagem, na visão de mundo, naquilo que o psicólogo vê e deixa de ver.

Mas a Psicologia é um campo de lutas. A hegemonia para a qual tende a ideologia nunca se realiza em sua plenitude. Há, hoje, um conjunto considerável de teorias e técnicas que possibilitam a crítica a esse viés. Em diferentes campos de atuação, seria injusto identificar a Psicologia contemporânea como instrumento de compromisso exclusivo com a dominação, desconsiderando longos anos de estudo e engajamento de gerações que se colocaram na contracorrente de tal tendência. Seriam muitos os autores e teorias que poderiam ser mencionados nesse campo, desde os primeiros críticos da psicofísica às atuais abordagens institucionais e histórico-culturais.

Nos cursos de graduação, o estudante logo percebe que está em um campo contraditório, de antagonismos mais ou menos pronunciados.
A trajetória de formação repete o processo histórico da Psicologia, suas crises, movimentos e embates. Essa tensão de pensamentos é um verdadeiro fogo cruzado; cada disciplina tem seu espaço, sua aula separada das demais e assegurada na estrutura departamental das universidades. Cabe, invariavelmente, a cada aluno, habitante dessa panacéia, estabelecer algum tipo de visão geral. Resta à sua consciência a comparação, o confronto e a elaboração de uma saída no que concerne à sua prática e reflexão futuras. É provável que nenhum estudante de Psicologia atravesse a graduação sem sofrer algum impacto frente a isso. Entre eles, os militantes, aqueles que se engajam ativamente na política universitária, nos parecem testemunhas singulares. ${ }^{1}$ São eles que tomam iniciativas para enfrentar os impasses que se apresentam: propõem debates entre professores, organizam eventos que discutam temas polêmicos em Psicologia, lutam por mudanças curriculares que tornem a formação mais engajada e combativa no que tange às questões sociais. Em resumo, os militantes experimentam o antagonismo entre preocupações sociais e aquilo que aprendem de uma forma ativa, tornando o que poderia encerrar-se em suas vidas privadas em inquietação pública.

Marialice Foracchi (1977) afirma que o estudante, enquanto procura traçar seu percurso de inserção na chamada vida adulta, estaria especialmente exposto às pressões da sociedade, ao conjunto de seus antagonismos e contradições, ora pendendo para a adaptação e a conseqüente realização das expectativas de sua origem social ora procurando alternativas para negar tal caminho. É exatamente essa angústia imanente à sua condição que o caracteriza como agente
1 Neste artigo, refiro-me ao movimento estudantile a militantes de esquerda orientado pela breve definição de Jacob Gorender, que entende, por esquerda, "o conceito referencial de movimentos e idéias endereçados ao projeto de transformação social em beneficio das classes oprimidas e exploradas" (Gorender. 1998, p. 11). 
singular, sendo o militante sua expressão política.

A práxis estudantil se expressa no descontentamento durante a formação. Não é sem motivos que o movimento estudantil denuncia os conteúdos excessivamente técnicos, destinados à produção de profissionais que servirão de maneira irrefletida, alienados em sua prática. Em contrapartida, defende uma universidade acessível à população mais pobre, que trabalhe formando cidadãos engajados que se ponham ao lado daqueles que combatem a opressão. São inquietações presentes entre os militantes dos mais variados cursos desde a fundação da UNE (cf. Poerner, 1979). Na Psicologia, os militantes lutam para incluir, em seus cursos, disciplinas que contemplem uma discussão acerca da relação entre homem e sociedade, entre sofrimento psíquico e desigualdades sociais; reivindicam conteúdos que se comuniquem, por fim, com sua militância, seja através da luta antimanicomial, seja nas escolas ou em qualquer outro espaço no qual o psicólogo atue profissionalmente (cf. Ribeiro, 1998).

Em regime de mestrado, procurei ouvir militantes do Instituto de Psicologia da Universidade de São Paulo (IPUSP). Agentes políticos dos tempos de graduação, foram testemunhas privilegiadas da contradição que enunciei e que é constitutiva do campo da Psicologia. Impasses que conhecemos teórica e politicamente são, aqui, manifestos em ações individuais, revelam-se como fontes de angústias que precisaram ser enfrentadas durante e depois da graduação. ${ }^{2}$ Suas lembranças nos obrigam a conceber a formação do psicólogo como um processo político e psicossocial, onde teorias, técnicas, instituições e sociedade de classes devem ser compreendidas de forma integrada.

\section{Método: a memória como trabalho}

Orientado pelos trabalhos de Ecléa Bosi (1994) e José Moura Gonçalves Filho (1999), procurei dar ênfase à perspectiva dos militantes, àquilo que eles lembraram e, lembrando, revelaram como essencial em suas vidas. Neste artigo, apresento um dos temas enfocados: a convergência ou divergência entre formação em Psicologia e militância.

Para o exame da participação política, aderi à modalidade semidirigida de entrevistas (Queiroz, 1991). O roteiro pretendeu mais provocar narrativas do que respostas dissertativas e que supusessem um gabarito. Nas entrevistas, busquei instaurar condições para a realização de um trabalho da memória (Bosi, 1994). Por meio de questões simples e capazes de reclamar uma narrativa, procurei provocar a lembrança de vivências concretas, episódios, fatos, espaços, objetos e pessoas: tudo o que a recordação recolhe, e, recolhendo, examina, julga e discute.

\section{Militantes}

Os entrevistados são estudantes do Instituto de Psicologia da USP. Vera atuou no movimento estudantil durante aproximadamente quatro anos. Foi, em 1992, uma das lideranças de uma greve estudantil pela construção da nova biblioteca do IPUSP. No ano seguinte, foi diretora do Centro Acadêmico lara lavelberg (CAII), dos estudantes de Psicologia da USP. Em 1994, integrou a diretoria do Diretório Central dos Estudantes (DCE) da USP; em 1995, assumiu o papel de coordenadora geral do DCE durante 
seu último ano de militância universitária. $\mathrm{Na}$ época da entrevista, como psicóloga, coordenava um aparelho público de saúde mental e atendia em consultório particular. Pedro militou no IPUSP de 1986 a 1992; participou oficialmente de uma gestão de centro acadêmico, em 1988, e esteve próximo de outras durante seu percurso, sendo referência importante para seus colegas. Esteve, por longo período, à frente da Executiva Nacional dos Estudantes de Psicologia (ENEP); acompanhou também as discussões do DCE da USP, além de ter participado de congressos da UNE. Pedro é professor universitário, atende em consultório particular e faz parte de um grupo de psicólogos que presta serviços a instituições educacionais. ${ }^{3}$

O movimento estudantil nunca deixou de comunicar-se com os acontecimentos políticos de sua época. Em diferentes contextos, episódios da História serviram de inspiração ou influenciaram seus rumos. Nos tempos de Pedro e Vera, final dos anos 1980 e início dos anos 1990, a esquerda é abalada pela queda do Muro de Berlim. Começa uma nova etapa, marcada pela hegemonia neoliberal e pela busca de rearticulação dos movimentos sociais, duramente golpeados dentro e fora do País. No Brasil recém-democratizado, os militantes enfrentam uma época difícil, sem rumos ou perspectivas definidos e tampouco a energia e vigor de outros tempos. Entidades estudantis acompanham a crise geral. Tempo magro para a política, mesmo assim, capaz de fomentar o engajamento no combate às desigualdades sociais.

As lembranças dos militantes refletem opiniões dos tempos de graduação, revistas na maturidade. Por vezes, são absolutos nas críticas que fazem. O mais claro exemplo disso é a clínica, rechaçada nos tempos de graduação e posteriormente assumida como prática profissional. Isso não desmerece as falas apresentadas; elas valem como primeiras impressões, impactos sofridos por jovens ao se depararem com contradições imanentes à sociedade e à Psicologia. Uma primeira impressão não é, necessariamente, pior que as posteriores. Ela é sintética, e, no caso dos jovens, é radical em seu duplo sentido: vão à raiz das contradições que percebem, mas se embotam, por vezes, em um pensamento extremado que não comporta ambigüidades.

\section{Sobre a interpretação dos depoimentos}

Durante o trabalho de análise, procurei considerar os marcos significativos em torno dos quais a vida se concentrou. Privilegiei o trabalho da memória empreendido pelos depoentes em torno daquilo que eles mesmos trouxeram e que pareceu decisivo em suas vidas. Como psicólogo social, tenho, como referência, discussões que Ecléa Bosi (1994 e 2003) estabelece acerca da memória. Para a autora, o tempo se organiza menos cronologicamente do que por eventos, acontecimentos singulares, o que chama de marcos de significação concentrada. A lembrança desnuda o que foi empobrecedor e o que foi enriquecedor. Revela aquilo que marcou, que foi alvo de investimento, de angústias e afetos. Pequenos instantes são trazidos com seus pormenores, vivos, suscitando intenso esforço do depoente no percalço dos acontecimentos, das pessoas, das datas e dos lugares. É esse árduo esforço que Ecléa denomina trabalho da memória: "na maior parte das vezes, lembrar não é reviver, mas refazer, reconstruir, repensar, com imagens e idéias de hoje, as experiências do passado. A memória... é trabalho" (1994, p. 55). 
É importante enfatizar que a pertença a uma classe não encerra apenas questões pecuniárias, mas uma perspectiva singular determinada por relações de produção que matizam, não de forma uníssona ou imperativa, mas como tendência geral, a maneira pela qualo homem percebe seu lugar no mundo e suas possibilidades de participação.
Como psicoterapeuta, reconheço que lembrar pode envolver a elaboração de uma experiência, pode trazer passagens permeadas de angústia e um conseqüente esforço para superá-las. Lapsos, esquecimentos, dificuldades para recordar deram margem a interpretações que levaram em conta conceitos psicanalíticos como os de trauma, angústia e elaboração (cf. Laplanche e Pontalis, 2002). A experiência, no movimento estudantil, pode ser permeada de passagens enigmáticas. Um ex-militante, retomando seu passado, pode esbarrar nesses episódios, e pode enfrentá-los ou não. A memória pode suscitar um trabalho de elaboração, ou seja, um esforço para tornar suficientemente reconhecível e consciente um acontecimento. Lembrar pode suscitar angústia, sofrimento, e pode também ser uma oportunidade de enfrentar e superar enigmas do passado, à semelhança do que acontece em psicoterapia.

Neste artigo, incursões teóricas estão em segundo plano. Procurei privilegiar o que Pedro e Vera lembraram, e, lembrando, revelaram acerca da trajetória de formação do psicólogo. Considero que as falas dos depoentes, melhor que um procedimento excessivamente analítico, dão dimensão mais exata de uma experiência complexa e, ao mesmo tempo, indissociável em suas múltiplas determinações.

\section{Apresentação e interpretação dos depoimentos}

\section{Antagonismos de classe}

Para a escolha dos depoentes, em momento algum tomei a origem social como critério, mas tanto Vera como Pedro se identificam com as classes pobres e sentem forte contraste frente à maioria dos colegas e professores, relembrando teses há muito conhecidas por autores marxistas, que apontam serem os proletários, por condições que Ihes são inerentes à sua inserção no sistema capitalista, mais dispostos ao engajamento. Segundo Goldman,

"Ele [o operário] não tem uma fortuna a fazer frutificar, situação social privilegiada a defender; para ele, os objetos não são "mercadorias", pois ele os vê unicamente pelo prisma do consumidor, pelo qual ele mantém toda sua riqueza e sua verdade concretas; os homens não perdem, para ele, suas qualidades vivas na abstração geral de "compradores", pois ele nada tem a vender-lhes e, o que é mais importante, ele pertence à única categoria social na qual os homens, mesmo para defender seus interesses mais imediatos, devem unir-se em vez de oporem-se uns aos outros. A solidariedade tem, para a vida social e para o pensamento dos operários, importância tão grande quanto o egoísmo e a concorrência para os burgueses e para as camadas médias" (1979, p. 141).

É importante enfatizar que a pertença a uma classe não encerra apenas questões pecuniárias, mas uma perspectiva singular determinada por relações de produção que matizam, não de forma uníssona ou imperativa, mas como tendência geral, a maneira pela qual o homem percebe seu lugar no mundo e suas possibilidades de participação. A concepção de classe não faz sentido sem o reconhecimento das contradições e conflitos imanentes à sociedade capitalista, sem, portanto, a percepção de que há diferenças pronunciadas entre um grupo que detém os meios de produção e outro, majoritário, que possui apenas sua força de trabalho, e que há exploração do segundo grupo pelo primeiro. 
Trata-se, também, de reconhecer as possibilidades de ação revolucionária que subjazem à perspectiva do proletariado (cf. Lukács, 2003). Tal acepção não desconsidera o variado matiz de grupos sociais que perfaz as chamadas camadas médias; tampouco leva, necessariamente, à visão maniqueísta, idealizada, da classe pobre. Enseja, sobretudo, uma diferença radical de posições, imanente à sociedade atual e que não pode ser desconsiderada, em que pesem outros referenciais, como nacionalidade, etnia, religião etc.

Embora seja atraente a conclusão de que jovens de classes populares estejam mais dispostos ao engajamento, ou que a participação destes comportaria características mais contestatórias e comprometidas com o combate às desigualdades sociais, é fácil perceber que, na universidade, nem todo estudante pobre se torna militante, e tampouco todo jovem rico é alheio à participação e identifica-se com valores conservadores. A pertença do indivíduo a uma determinada classe não deve ser tomada como determinante absoluto de suas idéias e ações, embora seja elemento essencial para compreendê-las. No horizonte de ricos e pobres, há tensões e contradições de uma sociedade dividida, o que, por si, traz possibilidades de resistência.

Logo na chegada ao Instituto, Vera sente-se como forasteira, entre gente estranha.

"Quando cheguei aqui, levei um susto. O pessoal se conhecia dos colégios, dos clubes... Com exceção de quem vinha de fora, de colégios públicos, ou de quem morava longe, todo mundo morava em Higienópolis, no Pacaembu ou na zona sul. As pessoas moravam perto, em Pinheiros e na Vila Madalena, mas não tinha ninguém que morava mais pra lá, onde eu morava, na zona leste. As pessoas iam às mesmas festas...

As pessoas falavam de coisas que eu não conhecia. Todos falavam outras línguas, falavam de cantores que eu não conhecia... Nunca tinha visto um apartamento que ocupasse um andar inteiro. Lembro que fui na casa de um colega estudar estatística e não entendi quando a porta do elevador abriu dentro do apartamento. Era o jeito de comer... Com aqueles talheres e guardanapos... Parece exagero, mas não é.

É claro que não era todo mundo. Eu me aproximei das pessoas que não eram assim, que não tinham carro, iam para casa de ônibus, que moravam longe, que comiam no bandejão... Isso era um divisor de águas.

Eu acho que foi muito por aí que a gente foi ficando amigo. Era o pessoal que ia no ponto de ônibus juntos. A gente ficava tirando xerox. Todo mundo comprava todos os livros. Lembro que, no primeiro ano, eu pedia xerox emprestado, tamanha era a minha dureza."

Pedro experimentou contraste semelhante. Sua situação é agravada na medida em que tem, desde o início, necessidade de trabalhar. A estrutura do curso de Psicologia da USP constitui grave obstáculo: o horário em tempo integral e a precariedade das formas de assistência estudantil desestimulam jovens de classes pobres a optarem pelo curso. Nesse contexto, suas preocupações o tornam exceção entre os estudantes. Sente, como sua colega, diferenças entre ele e seus interlocutores; diferenças entre mundos e visões de mundo; sente hábitos que lhe eram estranhos e uma série de pequenas atitudes
As pessoas falavam de coisas que eu não conhecia. Todos falavam outras línguas, falavam de cantores que eu não conhecia... 
cotidianas que denotavam um verdadeiro abismo.

"Nos momentos de intervalo, de conversa, fui descobrindo que as pessoas eram bem diferentes de mim. Os assuntos que circulavam eram outros, as preocupações eram outras... Encontrei outras pessoas, outras visões de mundo... Pessoas de colégios tradicionais, que haviam passado férias na Europa... Eu era completamente alheio a isso. Não encontrei pessoas que trabalhassem, que tinham uma realidade parecida com a minha.

Não me sentia identificado com as posições das pessoas. A gente brincava sobre as coisas da aula, mas havia meus conflitos. Chegava em casa e pensava aquelas questões: "gente, eu não conheço ninguém; o que as pessoas acham de mim?" Aquela preocupação típica de adolescente, com a imagem que as pessoas têm de você, e em compreender isso para poder inserir-se nos grupos.

Então, não tinha muito trânsito ali, entre visões de mundo e experiências cotidianas. As pessoas falavam coisas que chegavam assim como voltavam. Eu não tinha o que dizer, não tinha o que falar a respeito. As minhas experiências não cabiam. Quem entenderia o cotidiano de uma pessoa que estava estudando e estava em busca de trabalho? Não dava liga."

O estranhamento que Pedro e Vera sentem não é vivido como uma atitude cujo sentido era humilhá-los. Os depoentes não se ressentem de ações que objetivassem ressaltar explicitamente desigualdades econômicas. Pelo contrário, afirmam que as pessoas eram acolhedoras, receptivas. Eis um episódio lembrado por Pedro:
"Quando digo isso, não quer dizer que eu estava aqui e as pessoas lá longe, mas eu via essas diferenças de uma maneira radical. Não é que as pessoas não fossem receptivas. Lembro de um exemplo disso.

Uma colega minha nos convidou para sua festa de aniversário. Ela morava no Paraíso com os pais. Foi um choque, porque chegamos naquele apartamento enorme, numa festa de queijos e vinhos, com uma mesa posta com tudo o que você possa imaginar. Eu e meu irmão fomos dos primeiros a chegar. A gente olhou para tudo aquilo, olhou um para o outro... O pai dela foi super simpático com a gente, perguntou se a gente queria vinho... $\mathrm{E}$ a gente olhava para a mesa... "Como vamos fazer?". Não fazíamos a mínima idéia! Tinham vários talheres, várias coisas, e aquilo, para mim, era completamente desconhecido. Eu virei para o meu irmão e falei: "espera alguém manusear esses bichos aí e a gente vê o que faz, ou então a gente come do nosso jeito e acabou!" Não sei se chamou a atenção. Eu fiquei um pouco assim... Foi como uma festa de quinze anos. Acho que ela estava fazendo dezoito, mas tinha uma conotação de debutante, tanto que, num certo momento, ela começou a tocar piano numa sala, fazendo uma exibição. Pensei: "gente, onde é que estou?" Isso é uma coisa típica da formação da mulher numa certa faixa social: francês, piano, essas coisas."

O contraste social não é algo explícito, rapidamente identificável pelos estudantes. Figura, por vezes, como incapacidade pessoal de integrar-se com os demais. As desigualdades se manifestam de formas sutis, mas cortantes. Estudar e trabalhar durante a faculdade, comer no bandejão, não conhecer certas músicas, não falar outras línguas... Tudo 
isso aparece como déficit no aluno pobre, e o faz sentir-se em situação inferior. Segundo Marilena Chauí (1997), a cultura e os hábitos da classe dominante tendem a se impor; as referências que o pobre traz consigo são rebaixadas, e sua condição aparece não como contradição, mas como espécie de subcultura ou cultura precária.

Nesse contexto, vale o paralelo com o tema da humilhação social, estudado por José Moura Gonçalves Filho (2003). Trata-se de impedimento de palavra e de ação, vertido em angústia para aqueles que a vivem. A humilhação social é sentida de fora, uma vez que deita raízes em antagonismos de classe, mas manifesta-se também por dentro, como algo pouco elaborado, um sofrimento que embota e rebaixa e cujo enfrentamento não é coisa simples. Um trauma, em sua acepção psicanalítica, nos toma como que por trás de nossas linhas de defesa, como algo que é parte de nós, mas que não nos pertence. Nesse caso, em especial, sua elaboração precisa de espaços públicos; precisa do encontro entre homens que se reconheçam como iguais e partícipes de um mundo comum. É necessário partilhar o que está na raiz da opressão, tornálo reconhecível e objeto de uma luta coletiva. É significativo que os militantes tenham identificado, na época, necessidade de união com os demais colegas. Vera lembra:

"Essa era a palavra do dia na época: "tem que integrar a Psicologia, tem que integrar o primeiro ano com o segundo, com o terceiro...". Integrar, integrar, integrar: era isso que as pessoas falavam o tempo inteiro."

O estranhamento que Pedro e Vera sentiram frente aos colegas matizou suas concepções acerca da Psicologia. Cabe identificar a aversão sentida em relação às disciplinas e professores, e como essas duas esferas se inter-relacionam. Cabe, também, apontar como a percepção de tais contradições se configura como potencial de crítica e renovação no interior da própria Psicologia, tanto nas trajetórias de vida dos depoentes como no contexto de formação em geral.

\section{Aversão à Psicologia}

O estranhamento de Pedro e Vera frente ao curso acentua-se na medida em que certas disciplinas são ministradas, especialmente aquelas que apresentam técnicas de classificação e diagnóstico - testes de QI, métodos de avaliação psicológica... Na época, a clínica é especialmente incluída nesse contexto: é, ao mesmo tempo, lugar e técnica da "burguesia". Vera lembra:

"Vinham aquelas psicanalistas e falavam dos casos delas de consultório. Eu pensava: Será que é isso? Será que Psicologia é só isso? Ficar falando do mundo interno? Tinha uma raiva da clínica! Me recusei muito tempo a fazer terapia. Nessa época, todos os meus amigos queriam ser clínicos, faziam análise não sei quantas vezes por semana. Eu dizia: "não faço e não quero saber!" Tinha a ver com essa minha raiva da Psicologia. Nem sei o que era direito, nem sei porque tinha tanta raiva... Estava ligada a uma bandeira contra a terapia, ao que ela representava socialmente.

Para mim, a clínica era algo a serviço do sistema, uma normatização de comportamentos, uma padronização do que você pode ou não pode fazer. Então, não ia fazer terapia de jeito nenhum. De jeito nenhum! Era uma bandeira. As coisas ficaram assim por muito tempo."

As "psicanalistas dos consultórios" e os colegas adeptos de onerosos processos terapêuticos 
são como que de outro mundo. A Psicologia clínica significa também, ela própria, instrumento de dominação a serviço dessa classe que habita o Instituto.

Pedro corrobora impressões de Vera. Ainda estudante, distingue a Psicologia clínica, genericamente, como espaço alheio aos demais. Tal apreciação é sustentada por sua experiência militante, pelos embates que se sucederam durante greves que participou, em que o Departamento de Psicologia Clínica aparece à parte, avesso às lutas e reivindicações da Universidade e do Instituto.

"Quando se levantava a questão relativa aos atendimentos, os professores rechaçavam, dizendo que a Clínica não deveria parar em hipótese nenhuma, porque "a relação com o paciente é a coisa mais importante!" Eles colocavam uma série de barreiras.

O Departamento de Psicologia Clínica sempre teve problemas. A grande maioria de seus professores era só supervisor. Nessa estrutura, coibiam a paralisação dos atendimentos. Vejo nisso, também, a participação restrita nas questões do Instituto e da Universidade. Eles não aderiam às greves. Eram os últimos a aderir, quando aderiam."

No final dos anos 1980, as instalações do IPUSP eram ainda barracões em caráter provisório, construídos em virtude da vinda dos estudantes do prédio da rua Maria Antonia no final dos anos 1960 e início dos anos 1970, logo após a batalha entre estudantes da Faculdade de Filosofia e do Mackenzie durante o regime militar (cf. Santos, 1988). Dando sinais de sua precariedade, muitos blocos começaram a apresentar problemas estruturais. Entre eles, o bloco da clínica tornase inviável para suas funções. Pedro, no quinto ano, participa das discussões acerca das providências a serem tomadas frente a essa situação e entra em confronto com seus colegas.

“Em 1989 e 1990, com a condenação dos melhores blocos, aquele debate histórico [entre a clínica e o resto do IPUSP] que acontecia se acirrou. Eu defendi a paralisação dos atendimentos com toda a força. Eu e o meu quinto ano brigamos nessa época; fui uma posição minoritária. Quando eu estava no quinto ano, já tinha uma ligação com as pessoas, mas fiquei irritado com a maioria delas, porque, no final das contas, decidiram da maneira mais triste possível. Resolveram atender naquelas condições porque queriam terminar o curso, mesmo com todas as condições apontando, naquele momento, uma paralisação. O meu ano e o quarto ano votaram em massa pela continuidade dos atendimentos. Eu fiquei passado! Isso mostrou para mim que as pessoas estavam realmente olhando para o próprio umbigo, decidindo em nome de questões pessoais. Vinham aquelas coisas: "eu planejei que vou casar no final do ano, não podemos nos prejudicar por causa da clínica..." Foram várias falas nesse sentido. As pessoas assumiram claramente que não queriam abdicar de um ano em prol da construção de algo maior. Isso foi um terror!"

Vera é ainda mais contundente nas críticas que faz. Para ela, quando a Psicologia entra em ação e procura explicar os fenômenos coletivos a partir do mundo interno, o estrago é grande, pois perdem-se as dimensões sociais de vista. A Psicologia é compreendida como algo de espectro obtuso e alienado.

Não é sobre o que acontece no mundo ou no País; é a ausência de contato da Psicologia com 
o que acontece na esquina! Minha impressão era que, sempre quando se falava sobre o que acontecia, o estrago era maior, pois se falava: "nós, aqui de dentro, técnicos do mundo interno..." Para mim, éramos técnicos do mundo interno, que olhamos aquela criança na rua, pedindo coisas no farol, e vamos falar sobre seus processos psíquicos... Umas coisas lamentáveis.

Pensava: já que a Psicologia tem essa leitura fechada dentro de seu consultório, então talvez dentro disso, como uma técnica de psicoterapia, seja boa. Achava que a Psicologia era isso: um benefício ao mundo privado. Ótimo, assim talvez ela faça menos estrago do que se propondo a ler a sociedade. Lembro que eu tinha muito essa impressão. A gente lia aquelas coisas todas sobre o Lula, o Fernando Henrique, como se a gente estivesse discutindo complexo de Édipo. Complicadíssimo.

O que estava sendo construído, para mim, era que a Psicologia era um instrumento para legitimar as desigualdades todas que existem. Ela estava completamente fora do mundo social. la vendo que não queria ser psicóloga, não conseguia ver que teria outra possibilidade de ser psicóloga, de fazer Psicologia fora disso. Era uma experiência muito ruim. A cada aula, ia indignando-me com o que as pessoas falavam. Achava que a Psicologia tinha que ser atacada, criticada. la construindo, para mim, que a Psicologia era um instrumento poderoso e perigoso a serviço do sistema.

Lukács (2003) há muito refletiu sobre as diferenças entre as perspectivas da burguesia e do proletariado não só nos campos econômico e político mas também no tocante ao pensamento. A ciência burguesa encerra questões imanentes à sua condição de classe, apresenta dilemas insolúveis, polêmicas cuja pertinência é questionável, lacunas que não pode preencher sem desfazer-se enquanto classe. Sem aprofundar o tema, as impressões dos depoentes lembram tais antinomias.

Em resumo, Vera e Pedro reconhecem, durante a graduação, três componentes integrados que formam uma espécie de gestalt, que repele e angustia. A Psicologia, e, especialmente, a clínica, representa um lugar, uma profissão e um instrumento de atuação para a "burguesia". O curso não comporta estudantes pobres. $\mathrm{O}$ olhar técnico aponta o "mundo interno", reforçando a importância dos mecanismos psíquicos individuais. Como produto final, a Psicologia representa instrumento de afirmação do sistema capitalista, técnica da elite e para a elite explicar e legitimar as desigualdades da sociedade de classes.

Vera e Pedro, hoje, são psicólogos, atuantes inclusive na clínica que criticaram com tanta ênfase. Mas, nesse momento, a Psicologia aparece enraizada em uma perspectiva bem definida, e a orientação que apresenta aos militantes é avessa aos seus ideais. $\mathrm{O}$ impacto que a formação acarreta não comporta sínteses, mas, principalmente, recusas, por vezes extremadas.

\section{Angústias estudantis, angústias profissionais}

Estabelecidas as perspectivas e impressões dos tempos de graduação, cabe agora acompanhar como Pedro e Vera identificaram possibilidades de se tornarem psicólogos. Suas trajetórias comportam, desde o início, diferenças.

Pedro não avalia - como Vera o faz - a Psicologia como algo absolutamente pertencente à classe 
dominante. Vislumbra, desde cedo, a possibilidade de uma atuação engajada, o que aparece logo no seu interesse pelo curso.

"Estava na adolescência e trabalhava numa livraria. Desenvolvi grande afinidade com as idéias anarquistas de contestação, de criação de espaços desvinculados de uma autoridade, de um poder que concentrasse isso em suas mãos. Tive contato com livros. Lia sobre aquelas questões típicas de adolescente:

"Estava na adolescência e trabalhova numa Iivraria. Desenvolvi grande afinidade com as idéias anarquistas de contestação, de criação de espaços desvinculados de uma autoridade, de um poder que concentrasse isso em suas mãos. sexualidade etc. Li muita coisa sobre isso, coisas boas e ruins, mas que me deram alguma luz. E fui cair nos livros de Psicologia. Peguei coisas do Reich, comecei a ver Freud, Jung... Fui-me interessando principalmente por aquilo que se referia à experiência da loucura. Sempre ficou essa pergunta na minha cabeça, e, a partir dela, eu começava a tentar entender o psiquismo. Fui-me interessando a ponto de dizer: "é isso que quero estudar". Deve ter tido também participação dos textos que li sobre política."

Psicologia e militância aparecem como campos associados antes do ingresso na universidade. Tal relação parece estremecida durante o curso, só restaurada nos últimos anos de graduação, quando Pedro entra em contato com disciplinas que o despertaram para os problemas que identificara na adolescência. Lembra, especialmente, de Psicologia escolar e psicopatologia geral. A primeira, pela perspectiva crítica e engajada, e a segunda, pela problemática trazida, pelo tema da loucura que lhe era tão caro.

Não foi tão difícil para Pedro vislumbrar, portanto, depois de formado, uma atuação profissional que integrasse suas preocupações sociais e aquilo que aprendeu durante a graduação. A experiência aversiva em relação à clínica ficou circunscrita, identificada não como única forma de atuação, mas como comprometimento inscrito na história da Psicologia e cuja contraposição é possível. Assim, depois de formado, pôde unir aquilo que, na graduação, parecia tão antagônico, vislumbrar que suas preocupações poderiam ser integradas com a atuação profissional em consultório. A atividade clínica pôde ter espaço quando houve possibilidades diferenciadas de atuação, configurando-se em prática comprometida com o outro e com a sociedade.

Não se trata de um happy end, espécie de redenção conciliadora do militante com a Psicologia. As contradições imanentes às práticas e pensamentos do psicólogo vividas na juventude persistem, agora sob outras condições. Junto aos impasses de antes, sobrepõem-se necessidades pecuniárias, compromissos de um profissional frente à sociedade, que não podem ser ignorados. $\mathrm{O}$ que parece distintivo em Pedro, no entanto, é um certo incômodo presente desde os tempos de graduação. Durante a entrevista, avalia:

"As experiências coletivas estão cada vez mais raras. É algo que fico pensando nas aulas, com os alunos, que é a crise das utopias. Se utopia é algo ligado a uma sociedade ideal, ligado de alguma maneira ao impossível, nem essa idéia é possível mais. Até a idéia de pensar um mundo melhor, de lutar por um ideal, não está sendo possível. Nem isso! Vejo, hoje, as pessoas muito mais preocupadas com a própria pele, qualquer coisa coletiva é vista com certa aversão. Vejo isso nos lugares onde trabalho. Todo mundo está mais preocupado em se manter individualmente do que assumir coisas em grupo. Os valores estão muito complicados, estão muito mais para uma ética 
individual do que para uma ética coletiva. Isso é degradante para as relações cotidianas.

Em todos os níveis, as pessoas estão utilizando, como "utopia", salvar sua própria pele. Ninguém quer pensar em algo maior: em entidade estudantil, em movimento social, em sindicato... Parece que ninguém quer perder; ninguém quer deixar de ganhar de forma imediata. E é preciso ser perseverante, dar um tempo para as coisas. Em todos os níveis, o que percebo é que todo mundo quer o melhor para si agora, e passa por cima de quem precisar.

Ao invés de achar soluções coletivas, as pessoas montaram uma trincheirinha subjetiva. Fico pensando naquele poema do Fernando Pessoa que diz não haver mais gente de carne e osso no mundo, não existir mais gente vil, gente que vai ao banheiro. Só existem doutores em tudo. ${ }^{4}$ As pessoas estão nessa linha; no mundo profissional da Psicologia, isso é muito corrente. Vão se fechando em certos grupos e acabou. Cadê o debate? Cadê a discussão? Todo mundo está aí, fechadinho, guardadinho, encastelado. Os muros são frágeis, os argumentos são frágeis, mas como as relações de poder estão cada vez mais intensas e nossas relações cotidianas mais degradadas, as pessoas fazem de conta que deve ser assim. Mas sabem que não pode ser assim. É duro. A gente está em qualquer lugar pensando de outra maneira, levantando questões, ainda mais quem esteve ou está embrenhado em um movimento social. A gente, em qualquer lugar, está buscando esse espaço coletivo. Mas ele hoje está muito difícil. Tem lugares em que procuro e não acho. Eu vou, chego sozinho, saio sozinho. Não tenho com quem discutir, e, quando discuto, vejo que a pessoa está hermeticamente fechada, parece que tem um campo de força e as palavras não chegam. A palavra não repercute no outro. Ela até considera, mas não vai adiante. É essa trincheira frágil que todo mundo constrói para viver as relações cotidianas."

Na universidade ou no trabalho, a mágoa sentida frente a opções individualistas persiste. A solidão sentida, no passado e no presente, é fenômeno que deita raízes em determinações sociais profundas. Para a Psicologia, afirma, os efeitos do isolamento e do individualismo são devastadores.

Mas o depoente nos dá pistas, caminhos para resistência que não podem prescindir de ações e preocupações que visem a fomentar iniciativas conjuntas. Nesse sentido, o movimento estudantil pode ser um espaço de ruptura, etapa na formação do psicólogo que possibilite o questionamento de uma certa visão individualista, hegemônica, no contexto atual. O depoente identifica diferenças entre os colegas que militaram e os demais.

“Como psicólogo, reconheço em mim e em quem participou um diferencial. É algo que salta aos olhos. A minha atuação profissional ganhou muito: a maneira de encarar as relações, de ouvir as pessoas, ter posicionamentos..."

Sem esse olhar, próprio de um psicólogomilitante, a atuação fica comprometida. Pedro reconhece esse prejuízo nas universidades privadas onde trabalha como professor.

"Não há esse espaço nas universidades privadas. Se elas investissem nisso seria muito interessante, mas não investem. Os alunos deixam de ter organização política, um monte de coisas, e ficam como passageiros, consumidores. É uma visão de ensino enquanto consumo. Se fosse algo no qual o aluno se implicasse, toda a organização seria diferente. Aquilo que penso em relação à saúde mental, 
à infância e à adolescência, aquilo que penso em relação às grandes bandeiras da Psicologia, ganha graças ao percurso que fiz no movimento estudantil. Ganha muito. Sem dúvida nenhuma, seria outra coisa se tivesse apenas sentado na carteira dentro da sala de aula. A gente ganha ao discutir com as pessoas, organizar, compor, decidir, assumir decisões, trabalhar em grupo, ver as dificuldades desses movimentos. O movimento estudantil é uma escola também, um outro momento da formação. As pessoas entendem que formação é assistir aula. Formação é você discutir o que você viu em aula, é estar num espaço de discussão com outros estudantes, é discutir ciência, é participar. É ir à assembléia de estudantes, ouvir e falar nesses espaços. É inseparável uma boa formação em Psicologia disso tudo. Não dá para separar psicólogo de assembléia, não dá para separar de uma conversa que surgiu no bar sobre Psicologia."

O olhar crítico e militante não se apóia apenas em disciplinas que apresentem leituras e autores de esquerda; é formado, principalmente, por espaços de ação e discurso, pelo campo da política, onde a práxis militante congregue aquilo que foi aprendido e é de interesse profissional com problemas sociais que o jovem ou profissional vive e identifica. A Psicologia não pode prescindir dos espaços informais e formais de convivência, reconhecimento e amizade, de espaços de ouvir e falar, de discussão pública (cf. Arendt, 2001). Democracia e formação do psicólogo aparecem como faces de um mesmo projeto e visão de mundo.

Vejamos, agora, o que Vera nos diz. Para ela, assumir a profissão foi mais difícil.

É importante esclarecer que a militante se filiou a um partido antes de ingressar na universidade. Na época do vestibular, escolhe a carreira menos por interesse concernente à área do que para estudar algo das ciências humanas e poder trabalhar no futuro.

“Durante o colegial, nunca pensei em ser psicóloga: "eu quero tanto ser psicóloga, ficar atendendo as pessoas". O que eu sabia é que gostava muito de estudar e queria fazer universidade, mas na área de humanas, porque era esse tipo de conhecimento que me interessava. Era apaixonada por História, até por conta do meu envolvimento político.

Eu digo que a minha escolha por Psicologia foi instrumental. Não foi para ser psicóloga. Isso eu construí depois de muito tempo. Nunca quis ser psicóloga. Pensei: "quero estudar, então vou fazer alguma coisa que, se eu precisar, trabalho com isso".

Mais que Pedro, Vera sente-se deslocada, em terra estrangeira, e confirma juízos conhecidos sobre a Psicologia, que habitam o imaginário de militantes e estudiosos das ciências humanas até o presente: seria uma ciência focada no indivíduo, insensível aos problemas sociais.

As técnicas de inspiração positivista decepcionaram quem estava ávida por estudar algo próximo à História, Filosofia e Sociologia. A prática profissional que buscava também não agrada, sendo avessa aos ideais políticos que cultivava.

Essa perspectiva persiste durante praticamente toda a graduação. A cisão é radical, e sua repulsa em relação à Psicologia só começa a ceder quando entra em contato com o que chama de "disciplinas críticas". Conhece os trabalhos de Maria Helena Souza Patto, contundentes nas críticas acerca dos testes psicológicos e do diagnóstico de queixas 
escolares; entra em contato com a fenomenologia, relativizando o olhar funcionalista e positivista do início do curso; lê Foucault, Adorno... Vera descobre que a Psicologia não se reduz ao behaviorismo, à psicofísica, aos testes ou à psicanálise dos consultórios particulares. Com o estudo de Reich, vem a possibilidade de conciliar pensamento clínico e política, de rever a concepção da profissão como técnica absolutamente "capitalista" e "burguesa".

Nesse período, Vera desencantou-se com a política. Sofreu cisões abruptas, passando a recusar a militância com a força que recusara a Psicologia. Se o movimento estudantil não representa um mal, também não há garantias de que represente sempre um bem, de que não esteja submetido a vicissitudes comuns às demais formas de organização. Por vezes, o embate estéril entre grupos antagônicos rouba a cena, e o que passa a contar é "ganhar" o centro acadêmico ou ter maioria no Diretório Central dos Estudantes (DCE). Se há, entre grupos, diferenças políticas profundas - e não duvidemos que há -, elas por vezes desaparecem. Sem aprofundar o tema, basta registrar que os espaços do movimento estudantil assumem, por vezes, contornos kafkianos, e fica fácil compreender porque a enunciação da palavra "política" ou a lembrança de partidos ou entidades, por vezes, figura tão aversiva aos jovens do presente (cf. Mortada, 2002).

Órfã da militância, fica em uma espécie de vazio. A militante fica sem lugar; abandona sua identidade para abraçar outra, ainda a ser construída. Concebidos como pólos opostos, os papéis de militante e de psicóloga dificilmente comportariam síntese. A passagem de um campo para outro é vivida sem tempo para elaboração e como necessidade premente no final do curso.

Nos anos finais da graduação, é na prática profissional de um estágio que Vera iniciará um projeto conciliador entre Psicologia e militância.

"Bati o olho nos murais e vi um cartaz de estágio da prefeitura. Passei na prova escrita e fui fazer a entrevista. Nessa entrevista, contei que não gostava da clínica, que ela estava dentro do sistema de dominação, de exclusão social, que eu não fazia terapia porque era contra. E elas, olhando para mim: "o que você veio fazer aqui?" - "Vim ver o que vocês fazem, uma última tentativa antes de decidir que eu não quero ser psicóloga" - "O que você faz?" - "Movimento estudantil, eu estudo Reich atualmente" - "Por que você não está fazendo terapia? Você sabe quem são esses pacientes?" Elas foram me encostando na parede, me encostando... Eu saí dali pensando que não poderia mesmo trabalhar lá. Pirei, cindi, mas fui fazer o estágio.

Sofri muito nesse HD (hospital dia). No primeiro dia, veio uma figurinha e me perguntou: "você está vendo aquele caixão ali no céu?". Não sabia o que dizer. Todo aquele meu discurso de crítica à Psicologia... Fui tendo experiências disruptivas. Sofri. Pensava: "meu Deus, que curso que fiz? Eu não sei nada!" Comecei a estudar. Fui me apaixonando pelo trabalho. Eu falava tanto que a clínica era para pessoas que não precisavam... Essas pessoas precisam demais! Essa estória de que a clínica é para os ricos que vão fazer análise, descobri que não é.

Resolvi ser psicóloga, tive outra dimensão do que é clínica, do que é psicanálise. Deu para amadurecer muito, deu para ver que a psicanálise não é só isso, não é esse horror. Acho que fiquei um pouco mais compreensiva com a Psicologia." 
Durante muito tempo, isso me perseguiu. Sentia uma certa culpa: "Como posso ter saído daquilo ali?" É como religião, que você nasceu numa e não pode mudar. Ficava pensando: "Meu Deus, estou traindo a causa!" Que causa? Mas eu me sentia assim.
Mesmo depois da experiência de estágio em HD, Psicologia e engajamento permanecem, durante algum tempo, em pólos opostos. Assumir a Psicologia não significava apenas escolher uma profissão, mas, sobretudo, negar a própria militância.

"Quando fui para o HD, durante um tempão fiquei pensando de mim tudo que eu pensava dos alunos quando estava no movimento estudantil. Quando você passa um tempo na política, acha que tem os militantes e as pessoas normais. Tudo aquilo que eu pensava das pessoas, os alienados, as pessoas que não são críticas, que levam sua vidinha burguesa, eu ficava pensando de mim. Então ficava me sentindo meio culpada... Tinha um mal-estar, mas resolvia não pensar no assunto.

Estava despindo uma roupa minha, uma espécie de uniforme. Como um paciente meu que trabalha no correio e anda o tempo inteiro com uniforme. Eu tinha virado isso. Grudou. Então, ia tirando isso e aprendendo a ser psicóloga, que foi uma coisa que, durante a faculdade, me recusei a ser. Sofria, sofria... Não queria mais pensar nesse assunto.

Durante muito tempo, isso me perseguiu. Sentia uma certa culpa: "Como posso ter saído daquilo ali?" É como religião, que você nasceu numa e não pode mudar. Ficava pensando: "Meu Deus, estou traindo a causa!" Que causa? Mas eu me sentia assim.

Foi bem devagar, bem lentamente, que percebi que, sem querer, fazia algumas coisas que eu só poderia estar fazendo por conta da minha história no movimento estudantil, mas só depois, achando que não tinha nada a ver com a minha militância. Comecei a perceber: "Puxa vida, mas eu já vivi essa situação em outro lugar; essas coisas que penso, o meu jeito de pensar a profissão, meu jeito de me inserir, tem a ver com a minha história". Tem três anos que estou formada. Só hoje consigo pensar que uni, que eu achei um jeito na minha vida profissional de integrar as coisas que construí na época em que fazia movimento estudantil. Não foi fácil."

Vera traz, à semelhança de Pedro, o olhar crítico dos tempos da graduação, agora vertido sobre as contradições e possibilidades de sua prática profissional. Ambos reconhecem que, para a atuação profissional em Psicologia, o olhar militante é elemento fundamental, sem o qual o trabalho perde sentido e fica restrito às repetições ideológicas individualizantes. Percebem que a preocupação com a subjetividade não pode prescindir da preocupação com o outro na esfera global da sociedade. Isso não implica desconsiderar os processos últimos de seu sofrimento, mas melhor acompanhá-los, encontrando, na intimidade, sinais também da sociedade.

Aqui, enfatizo, não se trata de uma espécie de redenção. A pressão que a ideologia exerce sobre os homens se manifesta de maneira diferente na juventude e na idade adulta, mas não desaparece. Se antes emergia através das crises frente ao curso e aos colegas, agora toma outra forma. O psicólogo, trabalhador como outros, é impelido a exercer seu saber recaindo em contradições e em práticas profissionais reificadas: é levado a substituir o qualitativo pelo quantitativo, o concreto pelo abstrato, assumindo, em seu domínio profissional e consciência, características imanentes à forma capitalista de produção (cf. Goldman, 1979). Pedro e Vera não estão livres disso, mas cabe considerar, a partir do que expus, as possibilidades de resistência que encontraram, (e que se) beneficiando-se, inegavelmente, das possibilidades de engajamento político durante a graduação. 


\section{Considerações finais: temas para pensar a formação em Psicologia}

Os militantes nos deixaram experiências singulares, irredutíveis uma à outra. Tantos fossem os militantes ou estudantes entrevistados, tantas seriam as vivências da intersecção entre Psicologia e ideologia. São evidentes as dificuldades em generalizar uma investigação qualitativa como esta, restrita a poucos depoimentos e circunscrita a uma instituição com características bastante peculiares. Nos cursos de Psicologia, em que medida encontramos tal elitização e antagonismo de classes entre os estudantes? A formação em Psicologia guarda diferenças significativas de instituição para instituição. No campo da organização política estudantil, também são notáveis as diferenças de universidade para universidade.

Apesar de tais ressalvas, os depoimentos nos impõem temas urgentes, indispensáveis para a reflexão acerca da formação. Suas trajetórias representam um embate que a Psicologia evita ou dissimula. Na Psicologia tal como configurada nas universidades, sobrevém uma frágil harmonia, implícita na mensagem de que campos tão contraditórios podem coexistir, bastando que cada um opte pelo seu nicho e se reconforte na proteção institucional de seu ambiente de trabalho. Nas escolas, nas instituições de saúde mental, empresas e universidades, uma vez contratado, o profissional se vê, geralmente, em uma situação confortável para se acomodar e fugir de tais impasses, ou impossibilitado de promovê-lo. Os antagonismos existentes deveriam vir à tona em uma esfera pública, mas a inexistência de tal debate nos cursos de graduação, a supressão deliberada de espaços públicos que congreguem estudantes, funcionários e professores já correspondem aos efeitos de uma posição política reacionária.
A perspectiva advinda das classes pobres encerra possibilidades opostas àquela hegemônica no percurso estudantil e profissional, levando em conta outras necessidades, outras possibilidades para as técnicas e teorias apresentadas na universidade. Marilena Chauí (1997) reflete acerca das possibilidades inscritas na cultura popular para o estabelecimento de um contradiscurso. Sem idealizações, é de se esperar que diferentes composições em termos de origem de classe no corpo discente impulsionem, mais cedo ou mais tarde, transformações também na formação oferecida a esses alunos bem como nas teorias desenvolvidas nas instituições de pesquisa. São notáveis as mudanças no ensino decorrentes de sua expansão para outras camadas sociais em diferentes momentos históricos, e é clara a relação entre tais transformações e a participação política estudantil (cf. Poerner, 1979 e Foracchi, 1977). Muda-se, enfim, uma perspectiva e um compromisso que acarreta estruturas políticas e institucionais na universidade determinada, bem como campos de interesse, práticas e pensamentos. Pensar a formação em Psicologia supõe, portanto, que pensemos a democratização de seu ensino.

O movimento estudantil pode configurar espaço em que uma certa práxis é possível, rompendo a calmaria aparente garantida pela estrutura das instituições de ensino. É na trajetória de militante que o futuro psicólogo define suas opções, trava o debate entre diferentes orientações políticas e teorias psicológicas; é na participação coletiva que pode romper o olhar hegemônico individualizante. Caso contrário, o estudante "entra sozinho e sai sozinho", como nos revela Pedro.

Deve-se observar um tema pouco abordado neste artigo. O movimento estudantil, assim como outros movimentos, sofre as vicissitudes da sociedade capitalista. Pedro e Vera se 
lembram de entidades tomadas por processos maquinais e burocráticos. No contexto atual, são cada vez mais numerosos centros acadêmicos que se organizavam à semelhança de empresas, com objetivos principalmente pecuniários. Nesses casos, são sabidos e freqüentes os atos de corrupção, e os militantes nada mais fazem do que uma espécie de treino para o mundo dos negócios públicos e privados, experimentando todos os vícios que lhe são imanentes. A partir dos anos 1980, também houve transformação na condição de estudante. Sem entrar nesse tema, basta registrar a descaracterização deste enquanto agente capaz da força e mobilização de tempos pregressos, observando que o engajamento estudantil não é garantia de ruptura em relação à ideologia, podendo acarretar, outrossim, mais uma experiência tomada pela reificação, à semelhança daquela que os militantes identificaram, de início, na prática psicológica (cf. Mortada, 2002).

Não cabe reafirmar o saudosismo que tão freqüentemente encobre as lutas dos militantes do presente, transformando 1968 em uma espécie de mito (cf. Cardoso, 2001) e vendo, no estudante de hoje, um ente alheio aos assuntos públicos. Na Psicologia, os militantes acompanham a luta antimanicomial, aproximando-se de uma causa importante em nosso campo de atuação. Nas universidades, participam ativamente das greves e lutas pela melhoria do ensino público. Grande parte deles esteve presente nos fóruns sociais, em Porto Alegre, novo espaço político, de contraposição ao Fórum Econômico Mundial. São experiências que matizam a formação do futuro profissional, mesmo em tempos de uma política partidária e institucional tão aversiva aos jovens.

Em geral, as discussões acerca da formação do psicólogo mantêm-se focadas sobre grades curriculares e conteúdos ministrados, relegando a segundo plano a democratização das instituições de ensino, lembrada mais como falácia demagógica do que como intenção legítima. Os dispositivos legais que convergem sobre esse tema são omissos ou insuficientes. O movimento estudantil, bem como mobilizações de professores e funcionários, são duramente reprimidos assim que emergem na luta por suas reivindicações. Tal quadro é incomparavelmente mais grave nas instituições particulares de ensino, onde as relações entre reitores, diretores e professores correspondem às de patrões e empregados, onde as relações entre alunos e instituição se equiparam às estabelecidas entre consumidores e empresa prestadora de serviços.

Associar participação política e formação não é algo imediato. No caso específico da Psicologia, se refletirmos a partir dos passos de Pedro e Vera, são termos indissociáveis: pensar formação significa pensar a democratização das instituições de ensino, seus espaços para iniciativa e participação de estudantes, funcionários e professores. $\mathrm{O}$ psicólogo deve ser um profissional para quem o isolamento das pessoas na sociedade contemporânea e a escassez de iniciativas conjuntas que visem o combate às desigualdades sejam focos de angústia, crítica e ação. Esse tema se torna ainda mais essencial em tempos de reforma universitária. 


\section{Samir Pérez Mortada}

Doutorando em Psicologia Social pelo Departamento de Psicologia Social e do Trabalho do Instituto de Psicologia - Universidade de São

Paulo (USP)

Rua Sílvia, 95, apt 54 Bela Vista 013301-010 São Paulo/SP

E-mai:mortada@uol.com.br

Recebido 20/04/05 Aprovado 03/11/05

ARENDT, H. A Condição Humana. Rio de Janeiro: Forense Universitária, 2001.

BOSI, E. Memória e Sociedade: Lembranças de Velhos. São Paulo: Companhia das Letras, 1994.

O Tempo Vivo da Memória: Ensaios de Psicologia Social. São Paulo: Ateliê Editorial, 2003.

CHAUI, M. Cultura e Democracia. São Paulo: Cortez Editora, 1997.

FORACCHI, M. M. O Estudante e a Transformação da Sociedade Brasileira. São Paulo: Companhia Editora Nacional, 1977.

GOLDMAN, L. Dialética e Cultura. Rio de Janeiro: Paz e Terra 1979.

GONÇALVES FILHO, J. M. Humilhação e Memória: alguns Elementos para o Exame Psicológico de um Sofrimento Político. São Paulo: Instituto de Psicologia da Universidade de São Paulo, Tese de Doutorado, 1999

Problemas de Método em Psicologia Social: algumas Notas sobre a Humilhação Política e o Pesquisador Participante. In BOCK, A. M. B. (org.) Psicologia e o Compromisso Social. São Paulo: Cortez, 2003.

GORENDER, J. O Combate nas Trevas. São Paulo: Ática, 1998.
LAPLANCHE, J. e PONTALIS J. B. Vocabulário da Psicanálise. Trad. Pedro Tamen. São Paulo: Martins Fontes, 2002

LUKÁCS, G. História e Consciência de Classe: Estudos de Dialética Marxista. São Paulo: Martins Fontes, 2003.

MORTADA, S. P. Memória e Política: um Estudo de Psicologia Social a Partir do Depoimento de Militantes Estudantis. Dissertação de Mestrado. São Paulo: IPUSP, 2002

PATTO, M. H. S. Psicologia e Ideologia. São Paulo: T. A. Queiroz 1984.

POERNER, A. J. O Poder Jovem: História da Participação Política dos Estudantes Brasileiros. Rio de Janeiro: Civilização Brasileira, 1979.

QUEIROZ, M. I. P. Variações sobre a Técnica de Gravador no Registro da Informação Viva. São Paulo: T. A. Queiroz, 1991.

RIBEIRO, M. A. ENEP (Encontro Nacional dos Estudantes de Psicologia): História e Memória de um Movimento. São Paulo: Dissertação de Mestrado, Instituto de Psicologia da USP, 1998.

SANTOS, M. C. L. dos (org.) Maria Antônia: uma Rua na Contramão. São Paulo: Nobel, 1988. 